\title{
Rethinking Ethnicity and `Otherness` in Early Anglo-Saxon England
}

\author{
James M. Harland*
}

This article considers a recent critical problematisation of the discussion of `Otherness in Merovingian archaeology, ${ }^{1}$ and extends this problematisation to the early mortuary archaeology of post-Roman/early Anglo-Saxon England. The article first examines the literary goals of Gildas' De Excidio et Conquestu Britanniae, and especially its representation of military activity, to reject popular arguments that Gildas' conceptual framework described the emergence of an authentic, 'post-colonial British ethnic consciousness that was grounded in a conscious rejection of Romanness and separation from a `Germanic«, barbarian other. The article then examines the early Anglo-Saxon cemetery of Wasperton, Warwickshire, and rejects previous interpretations of the site, which argue that its inhabitants expressed in burial the ideological demarcation of Romanness from a Germanic >Other<. Drawing upon the distinctions made by Gildas between legitimate and illegitimate military authority and the clear use of symbols of military ideology present at the site, the article suggests that such sites instead offer evidence for the material expression of a new military ideology which, though deviant from the normative expectations of civic Romanness, was primarily drawn upon by the inhabitants of early Anglo-Saxon England to make appeals for the inclusion of the deceased as key members of their communities.

Keywords: Anglo-Saxon; archaeology; late Roman; Otherness; identity; ethnicity; Gildas; historiography

`Otherness` has its conceptual origins in continental philosophy and psychoanalysis - origins often overlooked in its current popular usage. The ubiquity of the term is evident in its selection as the primary theme of the Leeds International Medieval Congress in 2017. But, as Guy Halsall has recently observed, the term's proper origins are not adequately considered in current archaeological work; Halsall proposes that too often in current scholarship expressions of difference are identified as `Otherness`, but the >Other<, as he puts it, »is not simply the unlike; it is the very negation of the same. $\aleph^{2}$

The problem he identifies has not escaped Anglo-Saxon archaeological scholarship, especially in those works which aspire to take a more theoretically nuanced approach to questions of identity. Let us take Toby Martin, as an example, discussing early so-called Anglo-Saxon furnished inhumation burials in the later fifth century:

\footnotetext{
* Correspondence details: James M. Harland, Department of History, University of York, Heslington, York, YO10 5DD. Email: djmh50o@york.ac.uk.

1 Halsall, Otherness and Identity.

2 Halsall, Otherness and Identity.
} 
...the elites who used cruciform brooches evidently saw themselves as distinct from, yet related to, the inhabitants of the homelands cited in their origin myths. Essentially, they were more interested in drawing links with the Germanic world than the Roman world, which alongside ongoing population movement into post-Roman Britain, created a growing sense of superior otherness from preceding Romano-British society [my emphasis]. ${ }^{3}$

What such putative signs of otherness in the archaeological record might mean instead is discussed later in this article, through a study of the early Anglo-Saxon cemetery of Wasperton, ideal due to its recent comprehensive publication and its significance for scholarship on early Anglo-Saxon identity. ${ }^{4}$ The first part of the article disputes the historical grounds for expressions of otherness, such as Martin proposes above, in the early Anglo-Saxon mortuary archaeology, clearing some ground regarding what can effectively be demonstrated about identity as it functioned in post-Imperial Britain. To clear such ground seems urgent as we witness a resurgence of nationalistic sentiments concerning the U.K. and its constituent nations, closely related to its departure from the European Union. Andrew Gardner has recently commented on the relevance of fifth- and sixth-century historiography in these contexts. He uncritically accepts, however, a common historiographical conception that there existed a resurgent, spost-colonial fifth- and sixth-century British identity, plainly separable from Germanic identity. ${ }^{5}$ The following disputes this contention.

\section{Challenging a British spost-colonialism}

Written sources are rare, but we have the polemical sermon by the ecclesiast, Gildas: the De Excidio et Conquestu Britanniae. ${ }^{6}$ The text is variably dated to between the late fifth and middle of the sixth centuries. ${ }^{7}$ Though the meat of the text is a polemical section attacking Gildas' contemporaries, it begins with a historical description of the Britons' prior sins and eventual ruin at the hands of the Saxons. ${ }^{8}$ Due to its apparently detailed discussion of events after the effective collapse of imperial authority in Britain, it has long been used as a fundamental source, in the absence of other options, for addressing all questions about the period. ${ }^{9}$ Yet it is far from straightforward for such purposes. The text is a moralising tract, in which Gildas condemns the rulers and (mainly) priests of the day, in the guise of an Old Testament prophet. It is well recognised that use of the De Excidio for constructing a straightforward narrative history is impossible, ${ }^{10}$ and no attempt to do so shall be made here.

\footnotetext{
Martin, Cruciform Brooch and Anglo-Saxon England, 184.

10 O'Sullivan, De Excidio, 179-181; Lapidge and Dumville, eds., Gildas: New Approaches, x-xi; Halsall, Worlds of Arthur, 53-55
} 
But Gildas can still supply useful information. He has been shown to have been the product of rhetorical training in the Hellenistic classical tradition, rather than the late antique monastic tradition, known for its eschewal of secular classical texts. ${ }^{11}$ This makes it especially interesting that Gildas' work, whatever its date, forms part of a clearly emergent transition towards Old Testament models of ideal kingship. This becomes clearest on the continent in the late sixth century, but Gildas could represent an early example. ${ }^{12}$ This process is widely recognised as forming one component of a fundamental reworking of relationships between ruling authorities such as kings and the polities they ruled, which characterised the onset of the early middle ages. This new formulation, though taking much from Roman precedents, did not represent the classical ideal as it would have been taught by a grammaticus or rhetor. ${ }^{13}$

In terms of genre, the text is best described as a casus, the making of a persuasive argument through successive logical points. ${ }^{14}$ In Gildas' narrative, the Britons are portrayed as a people, who thrive only through the provision of God's divine protection. In the first instance this is given to them after their adoption of Christianity, in the wake of Diocletian's persecutions. After numerous instances of rebellion this protection is removed, as punishment for the simultaneous rebellion of the Britons against both God and the Roman Empire. The latter is portrayed as the God-sanctioned legitimate ruler of the Earth, on account of the Romans' superior virtues. At various points in the text, contrasts are made between the moral qualities of the Romans, the Britons, and the Anglo-Saxons, always at the expense of the latter two. ${ }^{15}$ We will subsequently examine these in detail. An obvious but simplistic reading of this, often the one put forward, would suggest that Britons had by this point become a distinct ethnic category which no longer regarded itself as Roman, and that this ethnic consciousness was also very much separate from, if not dichotomous to, the hated barbarian interlopers, the Saxons. Most scholarship has interpreted Gildas in just such a light, partially based on the alleged British separatism mentioned above. ${ }^{16}$ Such interpretations lend too much credence to a singular interpretation of Romanness whilst insufficiently considering Gildas's intellectual milieu and the purpose of his text. Though our knowledge of these is imperfect, we have enough to reject such an interpretation.

As mentioned, Gildas likely received a traditional formal education in grammar and rhetoric, including schooling in the classics of the sort that was undertaken by elites and bureaucrats across the Empire in Late Antiquity. There is also evidence for links between the Romano-British and Northern Gallic churches in the fifth century, and of ecclesiastical correspondence networks that would ultimately link British ecclesiastics with the quintessentially Roman elites of southern Gaul. ${ }^{17}$ We may assume similar educative and thus ideological norms were shared by those who underwent formal education in Britain.

Sutherland, Imagery of Gildas's de Excidio Britannie; Halsall, Barbarian Migrations, 312-313. For discussion on this as a wider phenomenon see Hen, Uses of the Bible and Wormald, Kings and Kingship, 571.

13

14

15

16

Wormald, Kings and Kingship, 575-581.

O'Loughlin, Gildas and the Scriptures, 26-27.

Gildas, De Excidio, ed. Mommsen, 2-26.

Jones, The End of Roman Britain; Laycock, Britannia; Higham, King Arthur. An especially egregious recent example is Hustwit, The Britons in Late Antiquity, aspects of which are now published as Hustwit, Britishness.

17 Wood, Continuity or Calamity?, 14; Petts, Christianity and Cross-Channel Connectivity, 74-76. 
This education had a clear utilitarian purpose - the inculcation of the accepted ideology and normative values of the Empire among its administrators. This training was inseparable from the formal administrative structures of the Empire, and those who received it would have done so in the expectation that, in some respect, they would access and negotiate those hierarchical structures. ${ }^{18}$ There is evidence that suggests that such structures were still regarded as important by people in the west of Britain as late as the late fifth century. ${ }^{19}$ Gildas, then, was one whose education would have inculcated a very precise definition of what being >Roman< meant. This included both ethnographic expectations of citizens of the various provinces and of the behaviour that would cause one to deviate from the normative expectations of civic Roman identity. ${ }^{20}$

We can interpret Gildas' apparent departure from these normative expectations with more subtlety than those arguing for a British 'post-colonialism` allow. Gildas never identifies himself as a Briton, and, as Halsall notes, even the crucial battle of Mount Badon is described as fought not between Saxons and Britons, but between >citizens` and renemies` or srascals` (hostes /furciferes). ${ }^{21}$ Gildas does, however, describe Britain as the patria. This word requires comment. Some scholars see Gildas' description of Britain as patria (homeland) as evidence for his putatively British, separate from Roman, ethnicity. ${ }^{22}$ But the word patria had a long tradition of use by thoroughly Romanised writers all across the later Empire. ${ }^{23}$ Imperial ideology promoted the unity of one's two patriae, that of one's origin and the adopted patria, the res publica. ${ }^{24}$ The applicability of this to Britain in this period is normally contested on the grounds that some degree of separation between Romans and Britons emerges in Gildas' text. Turner, for example, proposes that a simple maintenance of any distinction at all of provincial from Roman identity was unprecedented, and that unique attempts at ethnic construction were present in Gildas' vision. ${ }^{25}$

To read so far into this distinction is unconvincing. Some scholars suggest this distinction contributed to the construction of a British post-colonial identity that they claim makes itself manifest in Gildas' text. ${ }^{26}$ But the Britons were hardly the only victims of such portrayals of provincials. Ammianus Marcellinus in the late fourth century describes the Gauls as reager for quarrels and soverbearing in insolence. ${ }^{27}$ Hustwit attempts to bypass the Gallic problem by adducing a putatively exceptional scale of hostility toward Britons, and through asserting that there took place in the later imperial period a process of provincial British ethnogene-

Brown, Power and Persuasion, 37-41. See Gerrard, Ruin of Roman Britain, 120-155, for a discussion of possible evidence for the negotiation of such structures in British contexts.

\section{Late Antiquity.}

23 Merrills, History and Geography in Late Antiquity, 31.

24 See, on this unification, Ando, Imperial Ideology and Provincial Loyalty, 60-70.

25 Turner, Identity in Gildas' de Excidio, 39-40.

26 Hustwit, Britons in Late Antiquity; Higham, King Arthur; Jones End of Roman Britain.

27 Celsioris staturae et candidi paene Galli sunt omnes et rutili, luminumque torvitate terribles, avidi iurgiorum, et sublatius insolentes. Ammianus Marcellinus, Res Gestae 15.12.1, ed. Rolfe. 
sis, brought about through their distinction from the Picts. He argues that the two groups nevertheless remained conflated by continental writers, and that the marginality that this engendered contributed to later British ethnic solidification. Though Hustwit makes many interesting observations, a large part of his argument here depends upon an entirely speculative reconstruction of a presumed, but non-extant, ethnographic description of Britain as it could hypothetically have been portrayed in Ammianus' works. ${ }^{28}$ The erroneous claim is also made that by the fifth century, southern Britain was perceived as a theatre of war, indistinguishable from the barbaricum, on the basis of an excerpt from Claudian's In Eutropium. ${ }^{29}$ The ssouth in Claudian's poetry here quite clearly refers not to the provincial Britons, but to the Moors in Libya, who are offered as the southernmost contrast with the far north of Caledonia. These regions represent the limits of the world. Given their clear association with the Mauri in the south, the pejorative discussion clearly concerns the Picts, and is easily explained by ethnographic convention. There is therefore nothing to support Hustwit's contention that in Claudian's words, a more barbaric perception of the provincial Britons pertained than the depiction of them as provincials as found in Ammianus Marcellinus. ${ }^{30}$

Likewise, the presence of such hostility in Gildas' works can be equally explained by ethnographic convention. It is likely that Gildas had read Orosius, ${ }^{31}$ and it is plausible that many of his perceptions of Roman virtue were inherited from this source. Perception of the Roman right to rule and concomitant inability of the provincials to govern themselves was hardly unique to scenarios where imperial authority had collapsed. This trope was commonplace whenever authors discussed the relationship between the Empire and its provincials. ${ }^{32}$ We can only assume that marginality formed a core, internalised component of British identity if we accept that authors such as Gildas were actively constructing a British ethnos. But Gildas' identity remains an open question. He never identifies himself as a Briton, and it is noteworthy that Gildas never once explicitly uses words suggesting his membership of this patria; a patria is mentioned, but we have no secure reason to believe that it was his. If the De Excidio as a text actively sought to create an ethnos, it is remarkable just how infrequently the word Britannia and its derivatives appear in it. Britannia in various declensions appears twelve times, ${ }^{33}$ Britannus, >Briton`, a mere twice. ${ }^{34}$ These hardly seem the markers of conscious ethnic boundary construction. ${ }^{35}$

28 Hustwit, Britons in Late Antiquity, 132-139.

29 Hustwit, Britons in Late Antiquity, 151-152. Caledoniis posuit qui castra pruinis, qui medios Libyae sub casside pertulit aestus, terribilis Mauro debellatorque Britanni litoris ac pariter Boreae vastator et Austri. Claudian, Carm., 5, 391-393.

30 Hustwit, The Britons in Late Antiquity, 150-152.

31 Wright, Did Gildas Read Orosius?

32 Ando, Imperial Ideology and Provincial Loyalty, 67.

33 Gildas, De Excidio, 1.14, 3.1, 4.3, 7.1, 10.1, 14.1, 21.4, 27.1, 33.2, 36.1, 39.1, 66.1, ed. Mommsen.

34 Gildas, De Excidio, 6.2, 20.1, ed. Mommsen.

35 Turner's sole evidence for ethnic construction is an apparent unity of common purpose imposed by Gildas on the Britons through their depiction in the singular, rather than the plural as well as perceived collective traits. Turner, Identity in Gildas' de Excidio, 32-33. It is perhaps noteworthy that the excerpt from chapter 4 of the De Excidio which Turner provides as evidence of British self-identity uses Winterbottom's translation, rendering the rebelling cives as scountrymen<. 
Turner suggests that the sharpness of the distinction Gildas makes between Briton and Roman targets the >pretensions to romanitas « which are adopted by the kings targeted in his polemic. ${ }^{36}$ He identifies Gildas as an ethnic entrepreneur, but the notion that Gildas bemoans deviation from expected classical norms may offer an alternative reading. Turner suggests that such polities as Syagrius' 'Kingdom of Soisson< point to the possible presence of wider Roman political affiliation in the post-imperial British polities, though he suggests that a scarcity of documentary sources makes rendering such comparisons difficult. ${ }^{37}$ Even the very existence of a Roman skingdom of Soissons is doubtful. ${ }^{38}$ An alternative might be to turn to parallel situations on the continent where similar processes were taking place. Heydemann has outlined the means by which exegetical commentary on the Old Testament and the psalms could be used to renegotiate relationships between new gentes and the imperial ideologies undergoing substantial alteration, of which these renegotiations were a part, in the fifth and sixth centuries. ${ }^{39}$ In this case, in Ostrogothic Italy, a Latinate senatorial bureaucracy, epitomised by Cassiodorus, sought to harmonise and smooth over relations between their class and a barbarised, Gothic military class which now wielded hegemony over Italy under Theodoric the Great. ${ }^{40}$ Heydemann argues that Cassiodorus' exegesis formed part of a process of renegotiation of the relationship of the gens he described with a formerly hegemonic Romanness, now in flux. ${ }^{41}$

Though such a situation does not correspond directly to that of Britain, Pohl has shown that the processes of renegotiation of Romanness which took place in Britain were far from unique across the former Western Empire. ${ }^{42}$ The rough contemporaneity of Gildas to Cassiodorus suggests, when we consider Gildas' own exegetical style, that he was responding to the same wider geopolitical processes.

O'Loughlin's recent study of Gildas' exegetical method argues that its core function was the holding up of biblical scripture as a mirror to contemporary historical events. This mirror offered patterns in which could be found both the cause of problems and the remedy by which such problems would be solved. ${ }^{43}$ This mirroring was not the cyclical repetition of historical patterns but was caused by two constants, human sinfulness, and God's faithfulness to his own nature, which shaped with consistent patterning what were otherwise discrete historical events. ${ }^{44}$ The relationship Gildas identified between these historical events and the events described in scripture was therefore not that of ran inherent link between dissimilar realities but that of rexactly comparable situations`, which enabled the smaking [of] a diagnosis and prognosis of one's contemporary situation >on the basis of past experiences. ${ }^{45}$

\footnotetext{
36 Turner, Identity in Gildas' de Excidio, 45.

37 Turner, Identity in Gildas' de Excidio, 45.

38 Halsall, Childeric's Grave, 127-128.

39 Heydemann, Biblical Israel and the Christian Gentes.

40 Heydemann, Biblical Israel and the Christian Gentes, 149-150.

41 Heydemann, Biblical Israel and the Christian Gentes, 149-150.

42 Pohl, Romanness, 416-418.

43 O'Loughlin, Gildas and the Scriptures, 94.

44 O'Loughlin, Gildas and the Scriptures, 95.

45 O'Loughlin, Gildas and the Scriptures, 97.
} 
This has significant consequences for our understanding of how Gildas portrayed the Britons as a gens. O'Loughlin makes it clear that Gildas regarded the Britons as a gens sancta, imagining them through a biblical lens, whereby all of humankind were organised into gentes whom the apostles had been sent forth to baptise. It was the explicit welcoming of the gens into the ranks of the saved, through baptism, that made it corporeal. ${ }^{46}$ Britain, like Israel, had a covenant with God. This could be broken or forged anew through acts of sin or repentance. But for Gildas it was always the nature of Britain's relationship with God, whether one of distance or proximity, that made it a discrete historical actor, capable of acting in the history of the world. ${ }^{47}$

Thus, there is limited scope to see Gildas as what Rogers Brubaker might call an rethnic entrepreneur - that is, one consciously seeking the formation of an ethnos - but only in a substantially limited sense. Brubaker's ethnic sociology appeals for a move away from groupism, requiring that we reject the emic assumptions of such entrepreneurs when they appeal for the existence of the ethnic group qua group, asserting that ethnicity exists only in its iteration by such entrepreneurs. ${ }^{48}$ It is only in a specific eschatological role that Gildas treats the Britons as a collective entity. We cannot infer from this that Britishness was a trait readily distinguishable from qualities such as Romanness or Saxonness in other discursive contexts. We cannot assume that Gildas actively attempted to construct secular sociopolitical groups. Nor can we assume that Gildas' chastised contemporaries would have seen their own secular activities as defined by specific affiliation with such discrete cultural groups.

Still, there may be something to Turner's suggestion that Gildas' making of sharp distinctions between Briton and Roman was intended to target 'pretensions to romanitas '. A negative perception of secular warfare, and those who wage it, pervades Gildas' text. This owes, naturally, to the text's core purpose - to chastise the contemporary rulers and clergy of Britain for focusing on secular affairs - but something more significant for post-imperial society is identifiable. I will demonstrate that Gildas also deems the behavior of his contemporaries a deviation from ideals of normative civic Romanness, which he inherited from his educational background. This deviation is represented with the same schematic tools for all guilty of it, whether Roman usurper, Saxon federate, or post-Roman warlord.

Gildas' views about warfare and those who practice it appear at the very outset of his text:

Quia non tam fortissimorum militum enuntiare trucis belli pericula miti statutum est quam desidiosorum

It is not so much my purpose to narrate the dangers of savage warfare incurred by brave soldiers, as to tell of the dangers caused by the lazy. ${ }^{49}$

46 O'Loughlin, Gildas and the Scriptures, 113-114.

47 O'Loughlin, Gildas and the Scriptures, 114-115.

48 Brubaker, Ethnicity without Groups.

49 Gildas, De Excidio, 1.2, ed. Mommsen. 
Soldiers are mentioned rather frequently for a putative non-subject so Gildas appears here to be making use of preterition. The end of his preface reads:

vile quidem, sed fidele, ut puto, et amicale quibusque egregiis Christi tironibus, grave vero et importabile apostatis insipientibus

[My work pays a debt] I think, true to the faith, and friendly towards every young soldier [tironibus] of Christ, though burdensome and insupportable for foolish rebels. ${ }^{50}$

Tiro, which usually refers to young recruits, though it also, of course, refers to monastic novices, is often Gildas' chosen term to describe soldiers of Christ. We have a direct separation of apostate rebellious milites, from the tirones christi, who learn from Gildas' spiritual teaching.

This comparative scheme seems intentional. Gildas writes milites into the text with no obvious reason to do so if not to contribute to this scheme. Take here, in discussion of the Emperor Tiberius:

comminata senatu nolente principe morte delatoribus militum eiusdem,

For though senate were unwilling, the emperor threatened death to the informers against the soldiers of that same religion..$^{51}$

Gildas' source for this event, Rufinus of Aquileia, says:

Caesar in sententia mansit, comminatus periculum accusatoribus Christianorum Caesar held fast in his opinion, threatening with peril the informers against the Christians..$^{52}$

The insertion of militum is clearly Gildas' own. Meanwhile, there are two occasions when Gildas references soldiers in direct quotations from source materials. The first is taken from St. Paul's letter to Timothy. ${ }^{53}$ In the quote, Paul explicitly exhorts Timothy to sstrive to be a good soldier of Jesus Christ،. In the Gospel passage, Paul subsequently states: 'For he also that striveth for the mastery, is not crowned, except he strive lawfully, words that cannot have been far from the minds of Gildas' audience. ${ }^{54}$ Gildas' other direct quote of a description of milites is form St. Ignatius' speech as he is led to martyrdom, as described by Rufinus of Aquileia. This speech emphasises the animalistic qualities of the milites:

a syria usque romam cum bestiis terra marique depugno, die ac nocte conexus et colligatus decem leopardis, militibus dico ad custodiam datis, qui ex beneficiis nostris saeviores fiunt

From Syria as far as Rome I have fought with beasts on the earth and in the sea. Night and day I am bound to ten leopards, by which I mean the soldiers set to guard me, who are the more savage because of what I do for them. ${ }^{55}$

50 Gildas, De Excidio, 1.16, ed. Mommsen.

51 Gildas, De Excidio, ed. Mommsen, 8.

52 Rufinus of Aquileia, Historia Ecclesiastica 2.2.6, ed. Schwartz and Mommsen.

53 Gildas, De Excidio, 10.5, ed. Mommsen; Paul, Tim. 2.2.3-4.

54 Paul, Tim. 2.2.5.

55 Gildas De Excidio, 74.2, ed. Mommsen; Rufinus of Aquileia, Historia Ecclesiastica 3.36.7-9, ed. Schwartz and Mommsen. 
Both of these quotations are used in Gildas' polemic against the clergy, where a clear comparison emerges pitting the spiritual soldier against the secular soldier. The quote from Paul is especially striking, for its association with notions of legitimate military authority. Gildas therefore made use of soldier imagery to devise an explicit contrast between two types of soldier, to convey symbolic meanings in his polemic, and these meanings would have resonated with Gildas' depictions of rulers in the historical section and his polemic against contemporary rulers.

In his historical section, the illegitimacy of secular warfare becomes particularly striking in discussion of Magnus Maximus' usurpation:

itemque tandem tyrannorum virgultis crescentibus et in immanem silvam iam iamque erumpentibus insula, nomen Romanum nec tamen morem legemque tenens, quin potius abiciens germen suae plantationis amarissimae, ad Gallias magna comitante satellitum caterva, insuper etiam imperatoris insignibus, quae nec decenter usquam gessit, non legitime, sed ritu tyrannico et tumultuante initiatum milite, Maximum mittit.

At length the tyrant thickets increased and were all but bursting into a savage forest. The island was still Roman in name, but not in law and customs. Rather it sent forth a sprig of its own bitter planting, and sent Maximus to Gaul with a great retinue of hangers-on and even the imperial insignia, which he was never fit to bear: he had no legal claim to the title, but was raised to it like a tyrant by rebellious soldiery. ${ }^{56}$

The statement that the island sheld the Roman name but not its customs and laws is surely significant. Maximus certainly exhibits non-normative traits:

qui callida primum arte potius quam virtute finitimos quosque pagos vel provincias contra Romanum statum per retia periurii mendaciique sui facinoroso regno adnectens, et unam alarum ad Hispaniam, alteram ad Italiam extendens et thronum iniquissimi imperii apud Treveros statuens tanta insania in dominos debacchatus est ut duos imperatores legitimos, unum Roma, alium religiosissima vita pelleret.

[Maximus], with cunning artifice rather than virtue, attached all of the neighbouring districts, indeed even all of the neighbouring provinces to his illegitimate kingdom, and against the Roman state, using perjuries and falsehoods. He extended one of his wings to Spain, the other to Italy, and he established the throne of his unjust authority at Trier. With such insanity did he rage against his lords that he drove two legitimate emperors, one from Rome, the other, a most religious man, from life. ${ }^{57}$

Here we find a classic depiction of deviancy: a tyrant who sraged « with ssuch great madness against his master. This deviation lies, as Gildas takes great pains to emphasise, in a contest between legitimate and illegitimate authority.

After this, Britain becomes cut off from Rome, and suffers Pictish and Irish raids, before finally making an appeal for aid from Flavius Aëtius. ${ }^{58}$ This section makes no mention of milites or other foot-soldiers; when the Empire intervenes to aid the Britons, it is described collectively, as a legio, or an exercitus..$^{59}$ The one exception is a mention of the equites and 
nautae who 'planted in their enemies' necks the claws of their sword-points.$^{60}$ This can be explained by Gildas' literary goals: he weaves here an illustration of the rapidity, efficiency, and justice of the Roman military machine. ${ }^{61}$ It is here that Gildas tells us that the Britons, , [like] frightened chicks huddling under the wings of their faithful parents ... prayed that ... the name of Rome, which echoed in their ears as a mere word, should not be cheapened by the gnawing of foreign insult. ${ }^{62}$ The barbarian attacks, providential acts of God, ${ }^{63}$ are therefore caused by British military action against legitimate Roman rule, and Gildas directly associates them with deviation from romanitas. Not for no reason does Gildas, when the Picts and Scots again launch their onslaught, describe the Britons as 'weak in beating off the weapons of the enemy but strong in putting up with civil war and the burden of sin. ${ }^{64}$

When the Saxons enter the equation, as federates recruited by the superbus tyrannus, possibly Magnus Maximus, ${ }^{65}$ this scheme continues, and there is reason from this to believe that many of the binary divides assumed to have separated these two gentes, Briton and Saxon, were not as stark as is usually thought. As Halsall notes, once we reach this section of the text, where Britain has been stripped of its milites, the war becomes waged only between cives and hostes. Halsall suggests that this need not suggest battle between Saxons and Britons, but could instead signify civil war. ${ }^{66}$

The best evidence for this is the repetition of Gildas' plant growth metaphor, first used to refer to Maximus' rebellion, after the Saxons are invited to Britain:

inde germen iniquitatis, radix amritudinis, uirulenta plantatio nostris condigna meritis, in nostro cespite, ferocibus palmitibus pampinisque pullulat

Hence the sprig of iniquity, the root of bitterness, the virulent plant that our merits so well deserved, sprouted in our soil with savage roots and tendrils. ${ }^{67}$

The exact same word choices are used in this passage as in 13.1. The Saxons are depicted as a sprout of the same plant as Maximus. That they are little different should not be surprising. They, too, are rebellious soldiers:

igitur intromissi in insulam barbari, ueluti militibus et magna, ut mentiebantur, discrimina pro bonis hospitibus subituris, impetrant sibi annonas dari: quae multo tempore impertitae clauserunt, ut dicitur, canis faucem.

Thus, having been introduced to the island, the barbarians, as if soldiers who, as they falsely claimed, would accomplish hardships for their good hosts, were able to have the annona given to them. These provisions for some time closed the dog's mouth, so to speak. ${ }^{68}$

60 Gildas De Excidio 17.2, ed. Mommsen.

61 Gildas, De Excidio 17.1, ed. Mommsen.

62 For more on the positive imagery and fundamental romanitas which Gildas associated with the Roman military see Sutherland, Imagery of Gildas's de Excidio Britannie.

63 Gildas, De Excidio, 14, 19, ed. Mommsen.

64 infirma esset ad retundenda hostium tela et fortis esset ad civilia bella et peccatorum onera sustinenda. Gildas, De Excidio 21.1, ed. Mommsen.

65 Halsall, Barbarian Migrations, 519-526.

66 Halsall, Worlds of Arthur, 167.

67 Gildas, De Excidio 23.4, ed. Mommsen.

68 Gildas, De Excidio 23.5, ed. Mommsen. 
Words like annona and hospes suggest familiarity with typical processes of federate settlement. ${ }^{69}$ The Saxon's deceptive quality and comparison with dogs depict not merely barbarians, but soldiers behaving illegitimately. Sidonius Apollinaris' broadly contemporary portrayal of the Burgundian federates stationed on his estate offers a useful parallel. ${ }^{70}$ The tropes used to depict these federates are obviously exaggerated, using humour to clearly cast as an outgroup those coming to possess real military power in Gaul. ${ }^{71}$ Philipp von Rummel has suggested that such tropes were as much an aristocrat's disgust at the vulgarity of soldiers as any sort of reaction to real barbarism, ${ }^{72}$ and it is possible that Sidonius employed similar methods in his depictions of Saxons. ${ }^{73}$ The Saxons' behaviour and its condemnation thus seems little different from that of Maximus and his rebellious troops.

We have established that Gildas, in his historical narrative and use of biblical exempla, treated the depiction of illegitimate military activity as deviant from his normative values, whether perpetrated by Romans, Britons, or Saxons. Gildas' reference to the lugubri divortio barbarorum ('grievous separation from the barbarians`) might tell us more. ${ }^{74}$ The phrase is usually assumed to refer to a geographic boundary separating Britons from Saxons, which Gildas lamented for its denial of access to the tombs of British martyrs. ${ }^{75}$ Garcia argues that it should be understood better in a legal sense, referring to the breaking of the foedus under which the Saxons were settled, which entirely followed usual late Roman practice. ${ }^{76}$ If Garcia is correct, Saxon settlers were more intimately woven into the Roman and Latinate sociopolitical structures of the province than Gildas' rhetoric might suggest.

Can we take this further? If no such partition can be held to exist, and we no longer assume that conflict in Britain was always between Britons and Saxons, might both parties in violation of this contract be the rbarbarians`? We have already seen an animal metaphor used to illustrate Saxon barbarism, closely bound with their illegitimate military activity: the closing of the rdog's mouth. This is far from the only such metaphor. Leonine metaphors also feature with great prominence, including in descriptions of the new Saxon recruits. ${ }^{77}$ Lions are symbolically significant in early Christian thought because of their role in the deaths of the early Christian martyrs. St. Ignatius (whom we encountered above, cursing his leopardesque guard of milites) was, Gildas tells us, scrunched in the molars of lions at Rome. ${ }^{78}$ Moreover, Ignatius is described as a spiritual soldier, an example for lax priests. Gildas again employs the dedicated word he reserves for soldiers of Christ: tirones. In selecting exempla for this purpose, he asks why he should restrict himself to the prophets of the Old Testament, when he can spluck a few flowers with extended arm from the wide and lovely meadow of the holy young soldiers of the New Testament. ${ }^{79}$

69 Wood, End of Roman Britain, 20-21; Higham, English Conquest, 40-41.

70 Sidonius Apollinaris, Carmen 12, ed. Anderson.

71 Halsall, Funny Foreigners, 95.

72 Von Rummel, Habitus Barbarus, 171.

73 Harland, Imagining the Saxons.

74 Gildas, De Excidio 10, ed. Mommsen.

75 E.g., Sharpe, Martyrs and Local Saints.

76 Garcia, Gildas and the >Grievous Divorce`.

77 Gildas, De Excidio 23, ed. Mommsen.

78 leonum molis Romae confractus est. Gildas, De Excidio 74.2, ed. Mommsen.

79 ...carpentes paucos flores veluti summos de extento sanctorum novi testamenti tironum amoenoque prato. Gildas, De Excidio 73.1, ed. Mommsen. 
It is surely significant, then, that the proud tyrant (perhaps Maximus) associates with enemies described both as lions and as deceitful soldiers. Higham also notes the apparent comparisons that Gildas makes between other ignoble entities and the Saxons using leonine imagery. ${ }^{80}$ For Higham, the pejorative power of these passages lies in the suggestion that other parties described as lions were like the Saxons.$^{81}$ But it seems difficult to believe that it was the Saxons who were the primary signified for Gildas' use of this metaphor. The metaphor of a lioness first occurs describing Boudicca's revolt against Claudian, ${ }^{82}$ and is thus associated with rebellion against Roman legitimacy from its very outset, before any Saxons ever enter the picture. Sin, closely associated with illegitimacy, was surely the primary allusion.

This point is strengthened by the set of literary allusions present in one of the more well known leonine metaphors, that describing the Saxon slioness:

tum erumpens grex catulorum de cubili laeanae barbarae, primum in orientali parte insulae iubente infausto tyranno terribiles infixit ungues, quasi pro patria pugnaturus sed eam certius impugnaturus.

Then a pack of cubs burst forth from the lair of the barbarian lioness, first in the eastern part of the island, commanded by the ill-fated tyrant, they fixed their terrible claws, as if to fight for the homeland but in fact to fight against it. ${ }^{83}$

The above has been rendered thus in accordance with Woolf's proposal that the description of the Saxons' voyage across the sea is a later, non-Gildasian interpolation. ${ }^{84}$ The passage's resemblance to the afore-mentioned description of Roman military aid - an example of legitimate force wielded by the Roman state - is striking. Halsall has suggested that this chapter (17) and chapter 23 fall within the appropriate subsections of a sequence of paralleled historical scase studies', the former 'northern', the latter seastern', a point which Halsall uses to suggest the likelihood that Gildas' >proud tyrant` was Maximus. ${ }^{85}$ The high degree of similarity between the phrase describing Roman military action and that describing Saxon invasion has never, to my knowledge, been previously commented on. The Romans tandem terribiles inimicorum cervicibus infigunt mucronum ungues. ${ }^{86}$ Meanwhile, the Saxons in orientali parte insulae iubente infausto tyranno terribiles infixit ungues. ${ }^{87}$ Both parties plant their rterrible claws ${ }^{88}{ }^{8}$ Where the Romans plant theirs in the renemy<, the Saxons' plant theirs in the island, doing so on the orders of the sproud tyrantr. The comparisons of legitimate versus illegitimate military authority are undoubted. If the sproud tyrant « is indeed Maximus, this is reinforced even further.

80 Higham, English Conquest, 55-56.

81 Higham, English Conquest, 56.

82 Gildas, De Excidio 6.1, ed. Mommsen.

83 Gildas, De Excidio 23.3-4, ed. Mommsen.

84 Woolf, An Interpolation.

85 Halsall, Worlds of Arthur, 188-192, fig 9.1.

86 Gildas, De Excidio 17, ed. Mommsen.

87 Gildas, De Excidio 23, ed. Mommsen.

88 A similarity occluded completely by Winterbottom's translation. 
Gildas' concern was not these events, but the behaviour of his contemporaries. His main criticism of them was that they waged civilia et iniusta bella. A lion metaphor is also used to described the soldiers murdered by a prominent contemporary target of Gildas' criticism, Maglocunus:

nonne in primis adolescentiae tuae annis aunculum regem cum fortissimis propemodum militibus, quorum uultus non catulorum leonis in acie magnopere dispares uisebantur...?

Did you not, in the first years of your youth, use sword and spear and flame in the cruel despatch of your uncle and nearly his bravest soldiers, whose faces in battle were not very different from those of lions' whelps? ${ }^{89}$

These soldiers are clearly being associated with Maximus and the Saxons; all three deviate from legitimate behaviour through their participation in civil warfare. Gildas may even have been inspired by decorative motifs worn by some of these military men: the notitia dignitatum's depiction of shield patterns for comitatensian units generally believed to have been based in Britain includes beastly motifs easily interpretable as wolves or lions (Fig. 1), ${ }^{90}$ and such motifs are well known to have influenced later zoomorphic patterns found in such examples as early Style I jewelry and much later, the material at Sutton Hoo. ${ }^{91}$ These motifs had longevity.

In his comment that the soldiers were not so different from lions' whelps, we perhaps see an admission that the activities of Saxons and Britons and the methods by which they legitimized and consolidated power were scarcely distinguishable. The ethnic and political affiliations of these slion whelps ever clearly delineates ethnic boundaries in the shistorical section of his text. Where the polemical sections of his argument are concerned, it is clear that deviation from acceptable behaviour was a far more important ideological component of Gildas' polemical thought than any putative separation of Romans or Britons from Saxons or Picts.

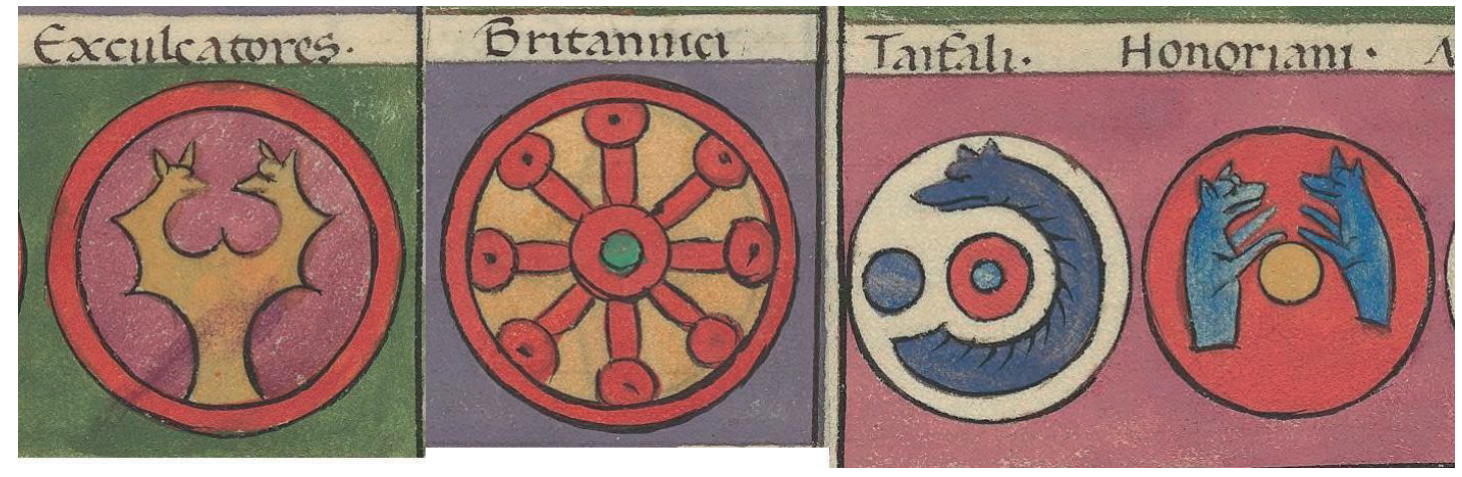

Fig. 1: Comitatensian units of the Comes Britanniae in the $>P \wedge$ Manuscript of the Notitia Dignitatum, Paris, Bibliothèque nationale de France, latin ms. 9661, (fol.111v, 112v-114v). The manuscript is Carolingian but there is good reason to believe these shield patterns are authentic. ${ }^{92}$

89 Gildas, De Excidio 33.4, ed. Mommsen

90 Notitia Dignitatum Oc. VII. 200-205.

91 Haseloff, Germanische Tierornamentik.

92 Brennan, Notitia Dignitatum, 159-160. 


\section{Problematising Otherness in the archaeological record}

There is every reason to believe that the ideological frameworks of power after imperial collapse still operated by association with Roman authority. Expressions of authority in the barbaricum are also known to have been shaped by such conventions before imperial collapse. ${ }^{93}$ The practice of burial in which we find putative archaeological evidence for rotherness s took place in large communal cemeteries. ${ }^{94}$ Large audiences participated in the funeral ceremony, drawn from the wider community and the buried's family. This audience, who normally held extensive feasts at these funerals, selected the repertoire of symbols deployed in burial. ${ }^{95}$

Wasperton (Warwickshire) is a mixed rite cemetery which has been fully excavated, containing 182 inhumations and 32 cremations. It is noteworthy for its putative evidence of continuity of burial from the late fourth through to the late sixth centuries, which is held to represent both the continuity and transformation of burial practice from that of late Roman to Anglo-Saxon. The site features sAnglo-Saxon « cremation urns that are radiocarbon-dated to the late fourth or early fifth centuries alongside slate Roman< inhumation burials. In the later fifth century its inhabitants began using so-called >Anglo-Saxon` furnished inhumation burials which lasted until the early seventh century. The cemetery was first identified through aerial surveys which identified prehistoric cropmarks and field systems. The cemetery was first excavated in the winter of 1980/1, in a rescue operation in response to gravel extraction from the terraces on which the side is situated. By 1985 the entire cemetery, in addition to numerous features from surrounding fields, had been excavated..$^{96}$

The site has been the subject of a few reports and one doctoral thesis. ${ }^{97} \mathrm{~A}$ final study of the site commenced in 2005, and aimed to set Wasperton in the context of English cemetery studies, drawing upon more recent technological developments such as advances in radiocarbon dating, stable isotope analysis, and multi-variate statistical analysis, in addition to the post-processualist theoretical advances of the 1980s and 1990s. This was published in 2009. ${ }^{98}$

\section{The current interpretation}

Inker, in his study of Saxon Relief Style metalwork in the Avon Valley, including Wasperton, suggested that this metalwork bore stestimony to the Anglo-Saxon settlement at an earlier dater than that historically attested by Bede. Inker thus drew a direct link between the material at sites such as Wasperton and Stratford and migrating Saxons. ${ }^{99}$ Inker also suggested that where variation in manufacture was concerned (such as an apparent adoption of manufacturing techniques from Britain in the case of cast saucer brooches), such processes reflected sincoming Saxons [...] utilising sub-Romano-British metalworkers to manufacture brooches and belt sets in lieu of brooches made by their own metalworkers. ${ }^{100}$ Such was

93 Halsall, Barbarian Migrations.

94 On which, see Lucy, Anglo-Saxon Way of Death.

95 See, e.g., McKinley, Spong Hill, Part VIII, 79-86; Halsall, Settlement and Social Organization, 247; Halsall, Burial Writes, 218-225; Williams, Well-Urned Rest, 107.

96 Carver et al., Wasperton, 1-10.

97 Scheschkewitz, Wasperton; Carver et al., Wasperton, 13.

98 Carver et al., 13-14.

99 Inker, Saxon Relief Style, 75.

100 Inker, Saxon Relief Style, 56. 
the impermeability of ethnic barriers for the transmission of manufacturing techniques, in Inker's view. That ethnic expression should be identified in isochrestic variation ${ }^{101}$ appears to have been a core (albeit not consciously stated) guiding assumption in Inker's approach to the ethnic signification of material culture. ${ }^{102}$ Such assumptions are now quite problematic. ${ }^{103}$ Grappling with this is important because such assumptions are crucial to Inker's inference of a coherent Germanic culture identifiable in the material from this region, a conclusion which others who study this region rely upon.

In his original study of the site, Scheschkewitz accepted uncritically arguments that differences in items of jewellery, such as cruciform brooches, wrist clasps, or saucer brooches, formed components of regionally distinct Trachten that could possibly be tied to distinct ethnic groups, partly on the basis of their functioning as components of peplos dress. ${ }^{104}$ Scheschkewitz proposed that it is problematic to take simplistic readings of ethnic expression as a component of such in material culture for granted, but he nevertheless follows Hines in asserting that the arrival of this material culture from Scandinavia and its subsequent spread across England represented an active declaration of sgroup membership<, which through the adoption of new performative traditions legitimised the presence of the new group. ${ }^{105}$ For Scheschkewitz, early Anglo-Saxon artefacts at Wasperton such as chip-carved equal-armed brooches demonstrated the >likely، Saxon ethnic origin of their wearers because of their geographic origin between the Elbe and the Weser. ${ }^{106}$

Scheschkewitz also proposed that the mixing of artefacts of >Anglo-Saxon or >RomanoBritish significance in the same chronological contexts or burials suggested the cohabitation of Romano-British or Anglo-Saxon populations, but argued that this did not clarify whether the presence of these artefacts was the result of an Anglo-Saxon stakeover . Scheschkewitz was principally concerned with whether or not acculturation was the cause of cultural change at Wasperton, and argued in the affirmative on the basis of, for example, burials that adopted >Anglo-Saxon` furnishings but followed the putatively >Romano-British orientation. ${ }^{107} \mathrm{He}$ suggested that possibilities for social protection, based on military power offered by federate Saxon migrants, enabled the Romano-British population to integrate into a social structure snot so foreign` to 'Celtic traditions of social power, based on systems of loyalty to small armed groups. ${ }^{108}$ In this reading the archaeological material is thus assumed to give an indication of distinct Romano-British and Anglo-Saxon ethnic groups and distinct >Germanic and >Celtic traditions.

101 The selection of particular options from equally viable alternatives to achieve a given manufacturing end. Sackett, Style and Ethnicity, 157.

102 As found, for example, in an assumption that re-use of repoussé technique indicated a desired connection with earlier `Germanic ancestors, Inker, Saxon Relief Style, 2-3.

103 Jones, Archaeology of Ethnicity, 111-116; Harland, Deconstructing Anglo-Saxon Archaeology.

104 Scheschkewitz, Wasperton, 183-185.

105 Scheschkewitz, Wasperton, 196.

106 Scheschkewitz, Wasperton, 196.

107 Scheschkewitz, Wasperton, 189-195. See especially discussion of Grave 169 from Spatial Group 3, 195. For more discussion on this see below.

108 Scheschkewitz, Wasperton, 198. 
Carver, Hills, and Scheschkewitz are subtler in their final report on Wasperton. They propose that burial continued without interruption between the late Roman and Anglo-Saxon phases of the site, ${ }^{109}$ though some of the chronological methodology underlying this argument has been problematised, suggesting that the authors cannot date artefacts as precisely through radiocarbon dating as they have suggested here. ${ }^{110}$ As with Hills' and Lucy's final report on Spong Hill, a far more nuanced approach to questions of social identity is present. The authors state that questions of whether culturally >Roman` versus culturally >Saxon` gravegoods represent different ethnic or kin groups is 'not resolved by the Wasperton evidencer and they accept that objects cannot be equated with crude ethnic and religious terms. ${ }^{111}$ The hypothesis that the authors propose suggests that Wasperton instead represented a small local community on a frontier of different intersecting cultural influences, who loosely selected cultural alignments based on varying political affiliations with no implications of shifts of the ethnic makeup of those making these affiliations, or necessary implication of large-scale population change. ${ }^{112}$

There are nevertheless problems. It is never made especially clear where, for these authors, ethnicity ends and political affiliation begins. A clear pair of cultural packages in opposition to each other, one >Roman<, one >Germanic is implicit in the statement regarding the possibility for resolution of the meanings of these grave-goods, no matter how multi-layered or fluid their precise iterations, no matter many references are made to ethnicity's multilayered nature, or how often the authors suggest that an >Anglo-Saxon« ideology, with no implications of the ethnicity of those expressing it, is what is discussed, rather than ethnicity. ${ }^{113}$ Assumptions are present that production processes may be defined by broad cultural categories such as >Germanic or >Romano-British`, and that acculturation may be identified between the two. ${ }^{114}$ It is also suggested that the arrival of the new cultural spackager represented the arrival of incomers. ${ }^{115}$ Positivist assumptions are made about the means by which ethnic identity might be inferred from the material record:

It is probably worth pointing out that even with an immense programme of dating cemeteries with perfect bones, there is unlikely ever to be enough material to generalise about Angles, Saxons and Jutes in the manner of Bede. ${ }^{116}$

The unstated implication of such a statement is that a sufficient volume of material, rather than overcoming problems of epistemology, would enable us to make such generalisations. That such material represented such things is, of course, possible, but it is empirically unverifiable that `Germanic grave-goods represent any form of coherent cultural expression of material meaningfully, recognisably sother from Roman material. ${ }^{117}$ What can be inferred instead?

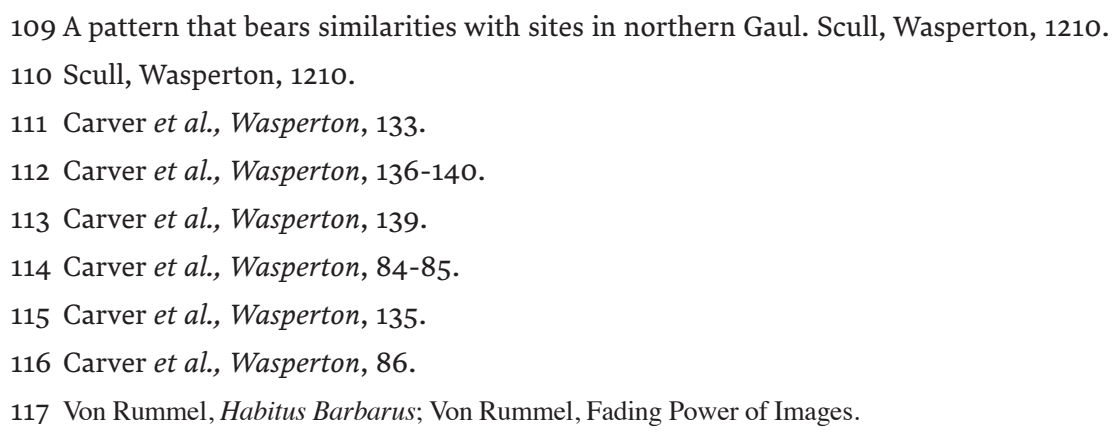


Let us turn to the earliest arrival of the putatively rother burial rite at Wasperton: socalled `Anglo-Saxon s style furnished inhumation. This is the sort of rite that Martin suggests expressed otherness from Romano-British communities. ${ }^{118}$ Spatial Group 3 is an ideal case study (Fig. 2).

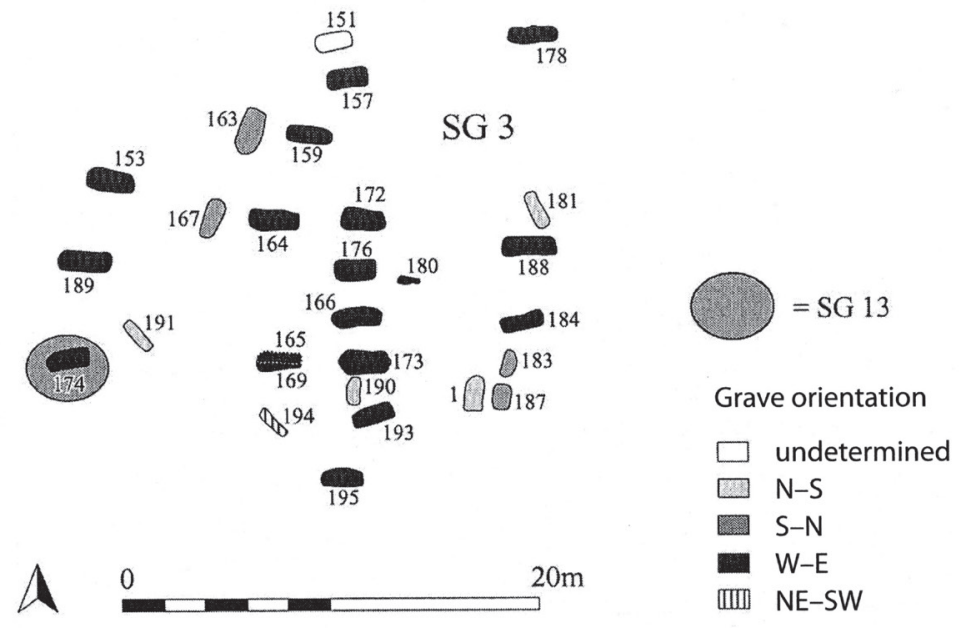

Fig. 5.4 The sequence in SG3

Fig 2: Wasperton, Spatial Group 3 (Carver et al., 107, fig. 5.4). Reproduced with the permission of the Warwickshire County Museum.

Burial in this spatial group begins either in the late fourth or early fifth century, in the form of inhumation of the dead wearing hobnailed boots, at first with disorderly orientation and no structural materials. As the fifth century progresses, the burials become consistently laid in a west-east orientation, and pieces of stone and planks line the interiors of the graves. Three burials with >Anglo-Saxon< style grave goods appear around 475 AD. The earliest, inhumation 165, contained an iron buckle, a strap-end, and a knife. But it was buried in the same manner as the burials before it: a west-east orientation and wooden and stone lining: an implausible candidate for sotherness،. Two other burials also contained so-called Anglo-Saxon grave goods, and these are slightly more interesting: 167 (Fig. 3) contained the sort of item that Toby Martin claimed expresses otherness: a pair of cruciform brooches, perhaps fastening in a peplos dress. Inhumation 163 (Figs. 4 and 5), meanwhile, had a pair of matching saucer brooches with chip-carved spirals and Style I decoration, as well as a pin, two iron belt buckles, various coloured beads and a small pot with decorations typically found on cremation urns from the period. These two burials deviated from the usual orientation, facing south-north. ${ }^{119}$

118 Martin, Cruciform Brooch and Anglo-Saxon England, 184.

119 Carver et al., Wasperton. 


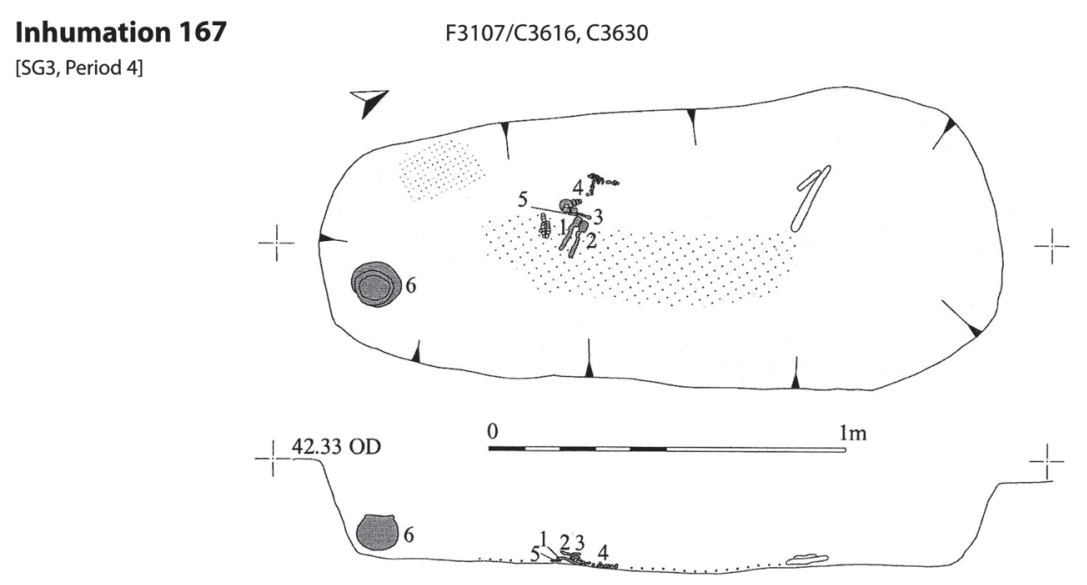

Detail of the plan above, rotated $90^{\circ}$ (scale 1:2)

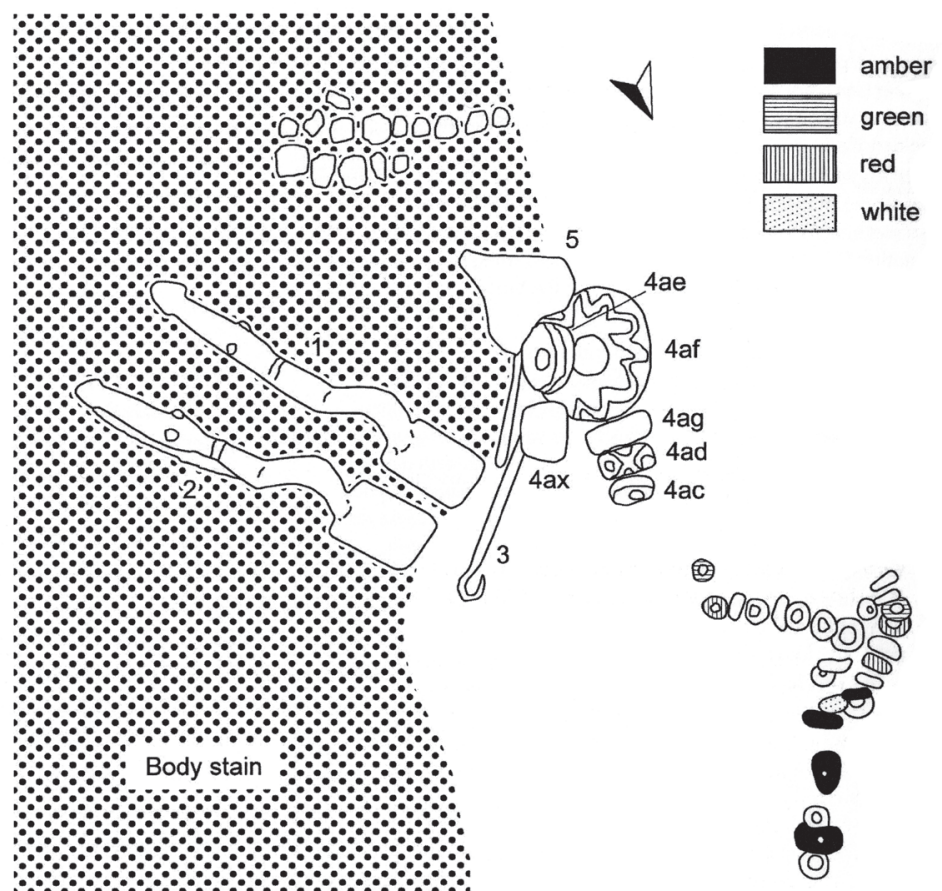

(2)

Fig. 3: Wasperton, Inh. 167. (Carver et al., 309). Reproduced with the permission of the Warwickshire County Museum. 
Inhumation 163

F3100/C3559-3560

[SG3, Period 4]

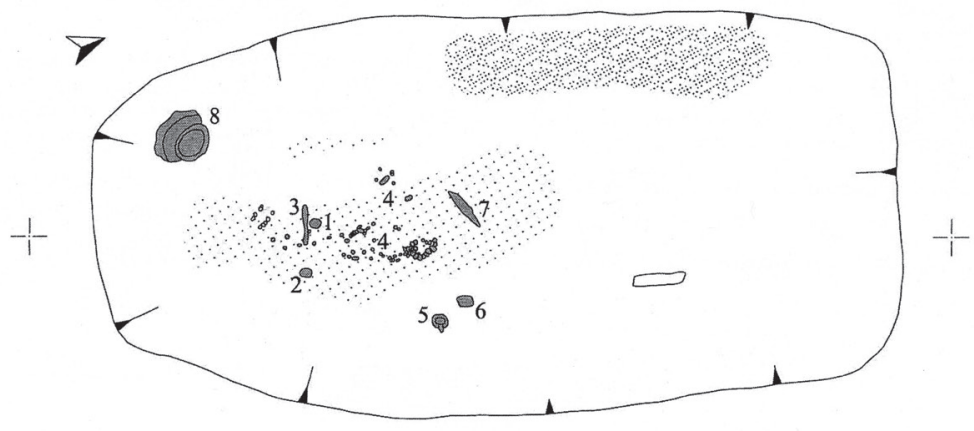

$1 \mathrm{~m}$

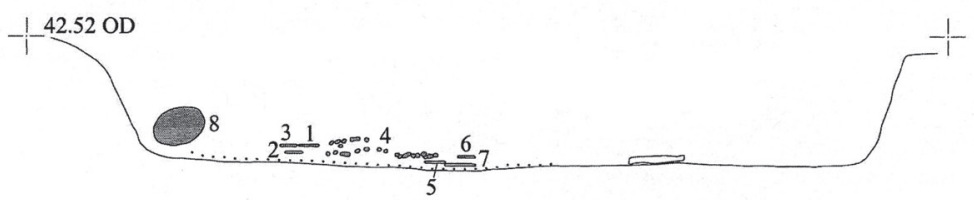

Fig. 4: Wasperton, Inh. 163. Reproduced with the permission of the Warwickshire County Museum.
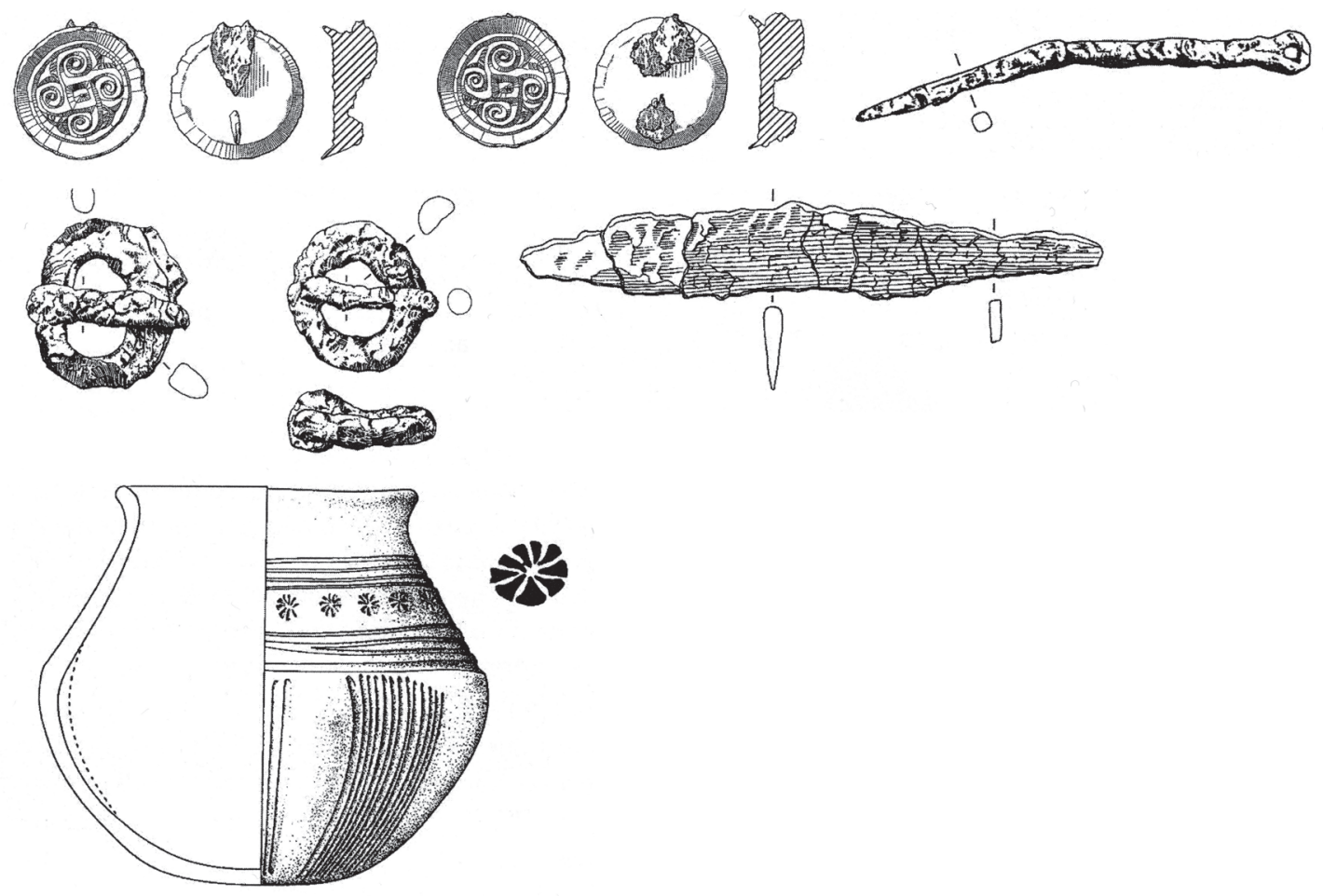

Fig. 5: Wasperton, Inh. 163 grave-goods (not to scale) (Carver et al., 302-303). Reproduced with the permission of the Warwickshire County Museum. 
The authors of the site report propose that in the later fifth century, a group of what they call sincomers appeared, using furnished inhumation with grave goods in the north-western section of the cemetery, while the east-west oriented burials continue under management of a sub-Roman family, and suggest that the cemetery underwent a shift in cultural affiliation as a result. ${ }^{120}$ But proving cultural significance is problematic. The pattern of burial is defined largely by its absence of furnishings (that is, its Roman character being defined largely by an absence of Germanic grave goods). ${ }^{121}$ Nevertheless, the two furnished inhumation burials do seem markedly different, and need explaining.

One simple possibility is that these two graves should be treated as part of a wider separation of the two types of funerary rite - the sSaxon< style graves are restricted to the western edge of the Spatial Group (Fig. 6).

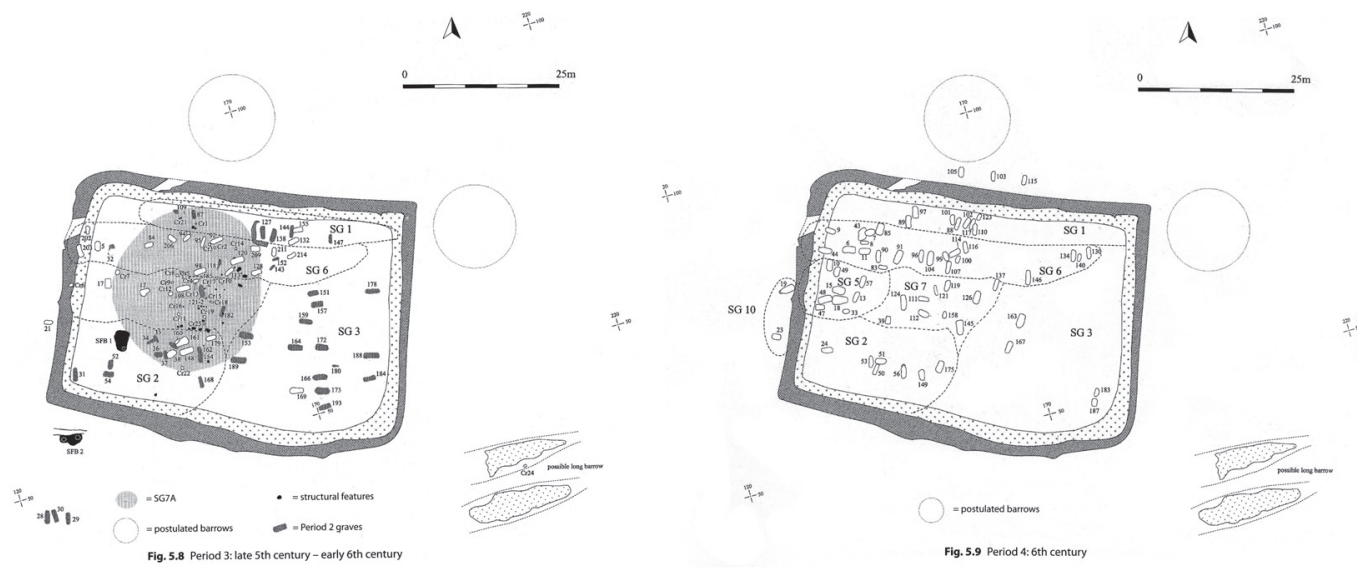

Fig. 6: Burials from Wasperton period 3, (late 5th c. to early 6th c., left) and period 4 (early to mid 6th c., right) (Carver et al., 117, fig. 5.8, 118, fig. 5.9).

Despite the problems noted above with the dating, there is no clear chronological break between the >Roman and the >Anglo-Saxon found on the saucer brooch in Inh. 163 is an early example of Style I's development from Nydam Style also found at Long Wittenham, making a mid-fifth-century date possible. ${ }^{122}$ Assuming a hard and fast chronological separation thus seems to oversimplify matters. The two S-N aligned burials both contain Style I fibulae, both orient at the same angle, a mere metre apart, in the middle of the, perhaps earlier, unfurnished ssub-Roman ' graves of Spatial Group 3. The continuity of burial at the site suggests that any burial taking place in this area would have proceeded with an awareness the W-E ritual was present in SG3. Inh. 167 was one of the earliest >Anglo-Saxon< style burials at Wasperton. We might ask whether these burials should in some way be deliberately read in relation to the burial rite at SG3. A traditional

120 Carver et al., Wasperton, 105.

121 The problems with such arguments will be discussed at length in Harland, Deconstructing Anglo-Saxon Archaeo$\log y$.

122 Dickinson, Anglo-Saxon Burial Sites, 61. 
reading would treat them as deliberate expressions of >otherness from the W-E rite, such as if we take Martin's understanding of Phase B cruciform brooches, for example. This seems unsatisfying. That Style I represents an emerging 'Germanic consciousness has no empirical basis. ${ }^{123}$ But Style I does definitely originate in provincial Roman military chip-carved metalwork. ${ }^{124}$ We have a means of bridging the gap between our material and the intentions of those using it in the clear references this material makes, however mediated, to provincial Roman military styles. We have no such bridge where putative >Germanicness is concerned.

Cruciform brooches are rare this distant from East Anglia. ${ }^{125}$ Nevertheless, despite the near complete absence of Martin Type 2 cruciform brooches from Warwickshire, another pair of the same precise type (2.1.2) found in Inh. 167 (Fig. 7), nearly distinguishable from those at Wasperton, has been found less than ten kilometres away, in the cemetery at Alveston Manor, Stratford-Upon-Avon, and was buried in an inhumation grave, with a Hawkes and Dunning Type I B belt buckle (Fig 8). ${ }^{126}$ Type I Bs are first used towards the end of the fourth century and continue to see use throughout the fifth. ${ }^{127}$ Interestingly enough, the same belt type is found with the female burial in grave 2, Dorchester-on-Thames, and Hawkes believed this to have definite military connotations. ${ }^{128}$ This particular buckle type has few continental parallels, and Hawkes thought it likely to be a type of British manufacture, inspired by its continental antecedents. ${ }^{129}$
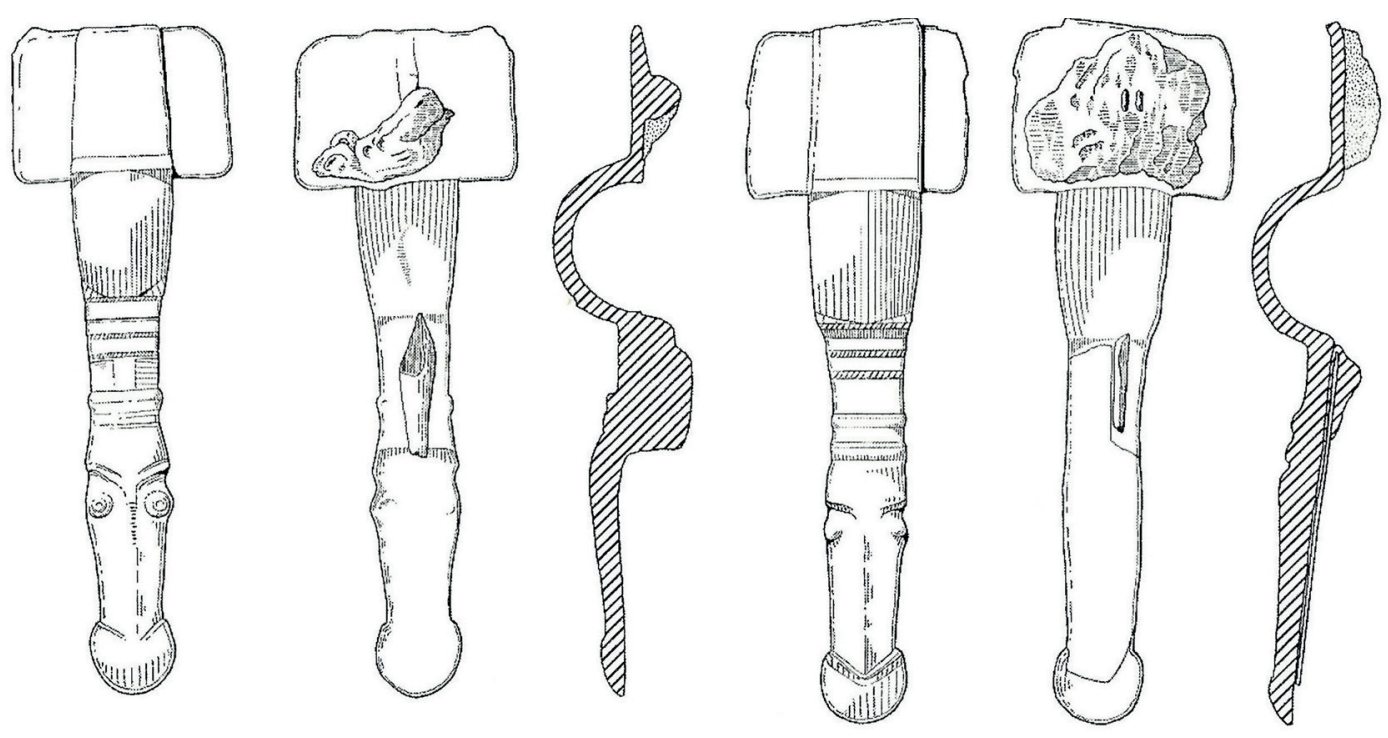

Fig. 7: Cruciform brooches from Inh. 167, Wasperton (Carver et al., 310). Reproduced with the permission of the Warwickshire County Museum.

123 Halsall, Space Between.

124 Haseloff, Germanische Tierornamentik, 16.

125 Martin, Cruciform Brooch, 31-32.

126 Hawkes and Dunning, Soldiers and Settlers, 48, fig. 16.

127 Hawkes and Dunning, Soldiers and Settlers, 26.

128 Hawkes and Dunning, Soldiers and Settlers, 28-9.

129 Hawkes and Dunning, Soldiers and Settlers, 28. 


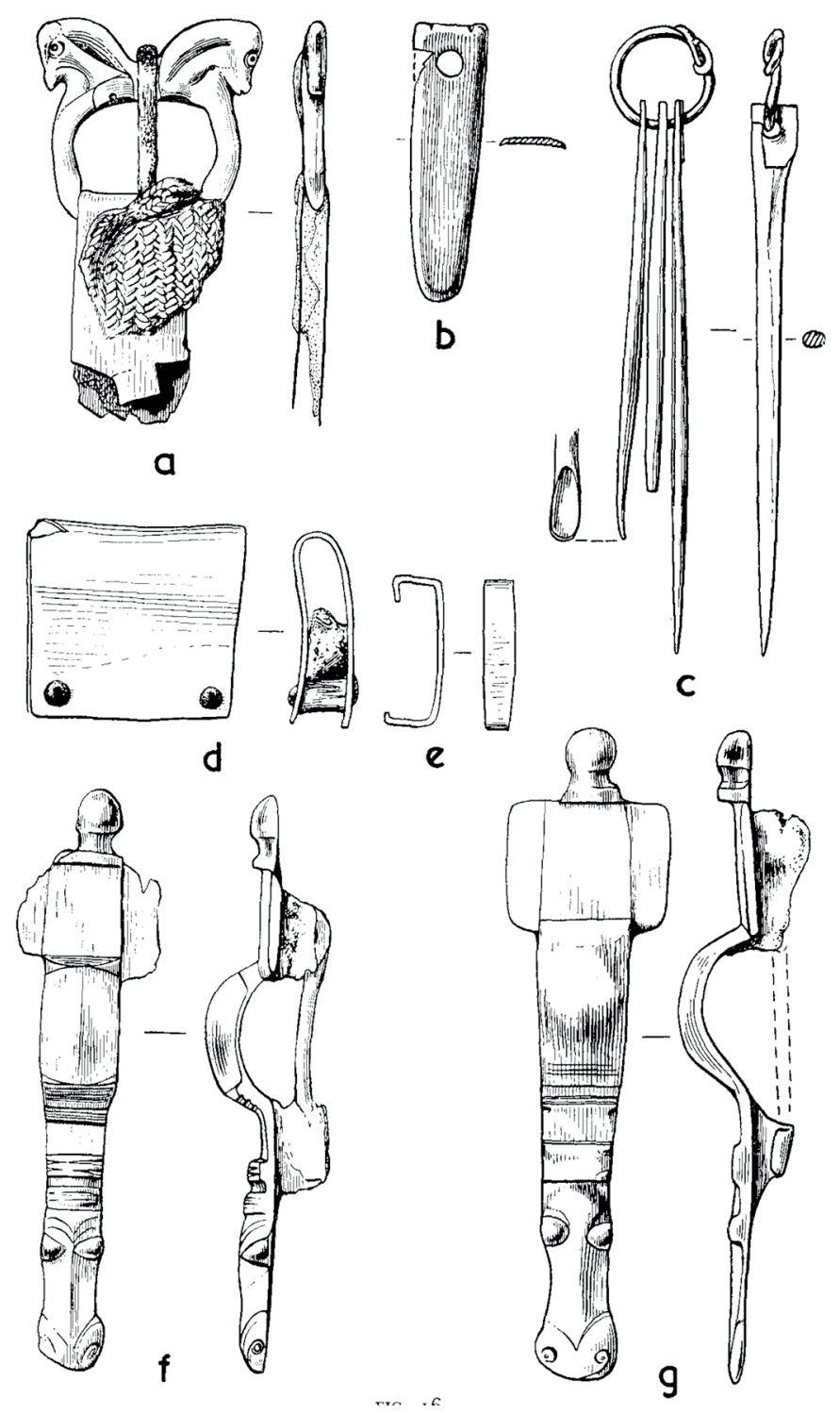

Fig. 8: Items including a pair of cruciform brooches ( $f$ and $g$ ) and Type IB buckle (a), Alveston Manor G7O (Hawkes and Dunning, Soldiers and Settlers, 48. fig. 16). Reproduced with the permission of the Society of Medieval Archaeology. 
Type I B buckles, like other British-manufactured late Roman belt buckles, possess somewhat distinctive and individualistic patterns of manufacture, suggesting individual construction rather than mass production. ${ }^{130}$ In Marzinzik's study of the type (II.1b as she calls it) the Alveston Manor find was noted to be exceptional for its discovery north of the Thames. ${ }^{131}$ Jarrett suggests that the distribution of unfinished and low quality buckles of this type may suggest production focused on the Cotswalds. ${ }^{132}$ Laycock argues that the distribution of Type IB buckles, as with the other types, is indicative of expression of a reemerging tribal civitas identity (in this instance Dobunnic), but we have no prima facie reason to accept such an argument. ${ }^{133}$ Still, the civitas was one of the primary organising units for the raising of armies in most of post-Roman Europe, so such distributions may have represented similar processes, producing distributions of metalwork based on civitas units, that nevertheless need carry no necessary implications about active expressions of identity - tribal, ethnic, or otherwise. ${ }^{134}$ Jarrett also suggests that the motif of confronted horse heads may have military resonances, perhaps suggestive of the comitatensian units of equites stationed in late fourthand early fifth-century Britain. ${ }^{135}$

Their appearance in later burials needs a bit more thought. Hawkes attributed the presence of such belts in later fifth-century burials to the plundering of Roman sites by AngloSaxons. ${ }^{136}$ This now clearly simplistic interpretation can be discarded. Type I B belts also did not survive long as a putatively military type without criticism. Hills rejected their identification as such on two grounds. First, that there was snothing "Germanic «about their themer, second, that owing to their usual burial with women, that they were possibly rcivilian, not military ${ }^{137}$ This argument employs two unhelpful binary distinctions. The first binary, that of Roman/Germanic, hinges upon a category of evidence defined by its other: it is difficult to think of a buckle type that could reasonably be called `Germanic<. Hills presumably had here in mind types with Saxon Relief Style decoration, but the reasoning for this depends upon an assumed cultural binary separating earlier, orderly, chip-carved metalwork (signifying Romanness) and later, disorderly chip-carved metalwork (signifying >Germanicness`). This separation has no prima facie basis - the only demonstrable aspect of the separation here, after all, is chronological, not cultural. ${ }^{1{ }^{38}}$ Marzinzik makes no further additions to this discussion, but instead simply follows the earlier analyses of Hawkes, Hills, (etc.) regarding

130 Laycock, Britannia, fig. 50a.

131 Marzinzik, Anglo-Saxon Belt Buckles, 36.

132 Jarrett, Ethnic, Social and Cultural Identity, 202, figs. 4.25, 4.26.

133 Laycock, Britannia. For problems with this see Halsall, Worlds of Arthur, 176-181.

134 Halsall, Warfare and Society, 45-46.

135 Jarrett, Ethnic, Social and Cultural Identity, 203. Notitia Dignitatum Oc. VII., ed. Seeck, 200-205.

136 Hawkes and Dunning, Soldiers and Settlers, 28.

137 Hills, Archaeology of Anglo-Saxon England, 305. This response came at a time when the nature of certain other 'Germanic items as representing the settlement of Germanic laeti or foederati was undisputed.

138 On problems with such distinctions, Halsall Space Between. Hills no longer adheres to such a rigid binary categorization but this specific example has still not been challenged and so it is necessary to do so to further the present discussion. 
these buckle types' putative `Germanicness‘, or lack thereof. ${ }^{139}$ Furthermore that such buckles were later buried with Style I jewellery should not be seen as an aberration needing additional explanation. Style I, after all, owed its decorative grammar to the same stylistic principles as the earlier jewellery. ${ }^{140}$

The second binary here reified, that of civil versus military decoration, also requires addressing. A point frequently made is that the late Roman cingulum was not merely a symbol of military authority, but rather a symbol of office, whether civilian or military. ${ }^{141}$ It is noteworthy that the male burial excavated at Dorchester-on-Thames in 1874 and the much more recent male burial from 2010 both contain buckles of Marzinzik's types II.1a (Hawkes and Dunning's Type III B), with niello inlay, chip-carved decoration and accompanying weapons. ${ }^{142}$ This type was almost exclusively found with men, both in Britain and on the continent, and usually dates, as Type I B, to the late fourth to early fifth centuries. ${ }^{143}$ There is general agreement that this type could perhaps be associated with military authority, but it is also noted that such belts were also used to express civil authority, and there is disagreement over whether this expression represented the Roman military (in some cases with suggestions of production in continental fabricae), the militarisation of provincials (perhaps more applicable for those types which are of local production, such as the I B) or claims to power through the expression of aristocratic hunting symbolism. ${ }^{144}$

Whatever one makes of the intricacies of these debates, the belts certainly resemble a deviation from idealised Roman costume norms that nevertheless have their stylistic origins on the Rhine-Danube frontier. ${ }^{145}$ That the Type II.1a should be associated with social competition, and expressions of authority based on the symbolic imagery of the Roman military frontier thus seems plausible. ${ }^{146}$ There is good reason to believe that the Dorchester burials represent a family community ${ }^{147}$ Furthermore, multiple Type I Bs were found in excavations in non-burial contexts at Dorchester - an unusually high concentration which may suggest production took place at the site, which is not implausible given the site's military context and its continued importance well into the seventh century. ${ }^{148}$ The Type I B was perhaps, therefore, the feminine accompaniment to the masculine militarised Type II.1a, but even the necessarily feminine associations of the belt cannot be securely determined. A mere five examples of the belt were used in Marzinzik's study, of which only three could be osteoarchaeologically sexed. ${ }^{149}$ This hardly reveals a statistically significant gendered rite. We

139 Marzinzik, Anglo-Saxon Belt Buckles, 4.

140 Martin, Cruciform Brooch and Anglo-Saxon England, 31-32.

141 Jones, Later Roman Empire, 566.

142 Booth, Late Roman Military Burial.

143 Marzinzik, Anglo-Saxon Belt Buckles, 35.

144 Hawkes and Dunning, Soldiers and Settlers, 161, Halsall, Origins of the Reihengräberzivilization, 205; Marzinzik, Anglo-Saxon Belt Buckles, 4, 84; Theuws, Grave Goods, Ethnicity, 307; Esmonde Cleary, Roman West, 82-90; Booth, Late Roman Military Burial, 268.

145 Von Rummel, Habitus Barbarus.

146 Fehr, Germanische Einwanderung oder kulturelle Neuorientierung?, 96-97

147 Booth, Late Roman Military Burial, 263-264.

148 Booth, Late Roman Military Burial, 265; Bede, Historia Ecclesiastica Gentis Anglorum 3.7, ed. Colgrave and Mynors. 149 Marzinzik, Anglo-Saxon Belt Buckles. 
should perhaps hesitate to identify a gendered use of this belt type in the early fifth century, given other artefacts associated with this artefact, which have also previously been assumed to have been female gendered, have turned out to be less easily identified as such. ${ }^{150}$ Thus, the full signification of the Type I B is difficult to determine but it cannot easily be separated from related, clearly militarised types.

Jane Hawkes noted over twenty years ago the multivalent and ambiguous signification of the animal art styles emerging in late fifth-century Britain. ${ }^{151}$ It seems doubtful that those who selected items bearing such styles to bury with their dead at Alveston Manor recognised the firm ethnic or cultural boundaries imposed on material types by the modern typologist: they surely would have seen such items as participating in the same semantic field of signification, and deployed them accordingly. The cruciform brooches at Alveston and Wasperton are sufficiently similar to be the product of the same craftsperson, and they are close enough geographically that people and thus ideas were probably shared across these two cemeteries. That these two burials in Spatial Group 3 expressed an authority that used the language of military power seems reasonable.

\section{Problematising Otherness}

But the acts of expression outlined above are not tantamount to >otherness،. Here, a recourse to the understanding of the concept as found in the philosophical school of differential ontology may be useful, to highlight how differing semiotic fragments are used, and what they signify. Let us consider Deleuze and Guattari's notion of the swar-machiner, forces of expression excluded from the norms of the state. ${ }^{152}$ For Deleuze and Guattari, the state is the classic operation of the master-signifier, the coalescing embodiment of an ideology that proceeds by the necessary distinction of Self from Other. ${ }^{153}$ The state maintains coherence by two methods: the violent method (control of legitimate force) and the judicial method (recourse to expected structures in the hierarchy of the state). These are

the principal elements of a State apparatus that proceeds by a One-Two, distributes binary distinctions, and forms a milieu of interiority. ${ }^{154}$

The state survives through imposing categories of meaning on fluid social processes. These categories shape definitions of interiority and exteriority that are determined by conformance to these categories.

In Gildas, we see the survival of the state's modes of ideological expression; his educative norms manifest in his condemnation of those who deviate from the elevated signifier - civic (as opposed to military) Romanness. Yet, as seen above, such condemnation is not solely applied to the Saxons. Instead the same discursive framework is applied more broadly, across post-imperial British society as a whole. This suggests that this society embodied Deleuze

150 Martin, Cruciform Brooch and Anglo-Saxon England, 214.

151 Hawkes, Symbolic Lives.

152 Deleuze and Guattari, Thousand Plateaus.

153 Deleuze and Guattari, Thousand Plateaus, 351.

154 Deleuze and Guattari, Thousand Plateaus, 352.

medieval worlds • No. 5 • 2017 • 113-142 
and Guattari's inversion of the state, the swar-machiner. The term as, they intend it, need not necessarily carry military connotations, but can instead be thought of as a difference engines, ideological expression that deviates from the state, breaking its closed operations open. In sub-Roman Britain, where a collapse of the state produced a society where bands of armed men gained power from appeals to military ideology, the military metaphor seems apt. But these two opposed forces, the homogenising, hegemonic force of the state, and the heterogeneous, unstable swar-machines, cannot exist without one another. Gildas' ideal behaviour could only be articulated through his identification of that which did not conform. Those who in Gildas's eyes would have been excluded from the expected civic norms of the Roman state now claimed power through expressions of military authority, using the shattered fragments of the formerly stable signifying regime.

This is why we cannot state that >otherness was present in Anglo-Saxon burial practice. In communal burial practice, where we find our evidence from early Anglo-Saxon England, the thing at stake is a claim for inclusion. Far from demonstrating a successfully achieved dramatic rupture from expected dress norms, expressions of difference in mortuary display emblemize attempts to ssmooth over or play down the buried's putative alterity. ${ }^{155}$ That is what we witness in our burials at Wasperton. Gildas would have condemned the people performing this practice, but could only do so in language that admitted the new normativity of the practice in post-Imperial British society. Meanwhile those who performed this practice demarcated themselves from those who did not, which possibly explains the deviation from West-East burial in Spatial Group 3 at Wasperton, but in deviating from the civic norm, they operated by the same rules. This burial rite's semiotic traces - some from north Germany and Scandinavia but with unknowable symbolic significance, some originating in Roman military imagery, do not express a >Germanic identity opposed to a declining Romanness. They appeal for the inclusion of this new community, using the only material resources available. These expressions of Roman authority might have been deemed barbarous and illegitimate by the likes of Gildas, but they were part of the normal symbolic grammar of authority in post-Roman Britain. This burial practice was far from >other«. It was a shining expression of participation.

\section{Acknowledgements}

This work was supported by the Arts and Humanities Research Council under Grant 1362784. I also wish to express gratitude to the anonymous reviewer for assisting me in producing a manuscript of greater clarity, and to Professor Guy Halsall, who supervised the doctoral thesis upon which this research is based and has been a helpful and encouraging source of guidance throughout.

155 Halsall, Otherness and Identity. 


\section{References}

\section{Primary Sources}

Ammianus Marcellinus, Res Gestae, ed. and trans. John Carew Rolfe, 3 vols. (London, 19351940).

Bede, Historia Ecclesiastica Gentis Anglorum, ed. and trans. Bertram Colgrave and Roger Aubrey B. Mynors (Oxford, 1969).

Claudian, Carmina, ed. and trans. Maurice Platnauer, 2 vols (London, 1922).

Gildas, De Excidio et Conquestu Britanniae, ed. Theodor Mommsen, vol. 13, Monumenta Germaniae Historica: Auctores Antiquissimi (Berlin, 1898).

Notitia Dignitatum accedunt Notitia urbis Constantinopolitanae et Laterculi prouinciarum, ed. Otto Seeck (Berlin, 1876).

Rufinus of Aquileia, Historia Ecclesiastica, in Eusebius 2.1: Die Kirchengeschichte, ed. Eduard Schwartz and Theodor Mommsen, vol. 6, Griechische christliche Schriftsteller (Berlin, 1999).

Sidonius Apollinaris, Carmina et Epistolae, ed. and trans. W. B. Anderson (London, 19361965).

\section{Secondary Sources}

Ando, Clifford, Imperial Ideology and Provincial Loyalty in the Roman Empire (Berkeley, 200o).

Booth, Paul, A Late Roman Military Burial from the Dyke Hills, Dorchester on Thames, Oxfordshire, Britannia 45 (2014) 243-273.

Brennan, Peter. The Notitia Dignitatum, in: Claude Nicolet (ed.), Les Littératures Techniques dans l'Antiquité Romain: Statut, Public et Destination, Tradition, Fondation Hardt 42 (Geneva, 1995) 147-178.

Brown, Peter, Power and Persuasion in Late Antiquity Towards a Christian Empire (Madison, WI, 1992).

Brubaker, Rogers, Ethnicity without Groups (Cambridge, MA, 2004).

Carver, Martin, Hills, Catherine and Scheschkewitz, Jonathan. Wasperton: A Roman, British and Anglo-Saxon Community in Central England (Woodbridge, 2009).

Deleuze, Gilles and Guattari, Félix, A Thousand Plateaus: Capitalism and Schizophrenia, trans. Brian Massumi (Minneapolis, 1987).

Dickinson, Tania. The Anglo-Saxon Burial Sites of the Upper Thames Region, and their Bearing on the History of Wessex, circa AD 400-700. Unpublished PhD Thesis (University of Oxford, 1976).

Esmonde Cleary, Simon, The Roman West, AD 200-50o: an Archaeological Study (Cambridge. 2013).

Garcia, Michael, Gildas and the `Grievous Divorce from the Barbarians`, Early Medieval Europe 21/3 (2013) 243-253.

Gardner, Andrew, Brexit, Boundaries and Imperial Identities: a Comparative Review, Journal of Social Archaeology 17/1 (2017) 3-26.

George, Karen, Gildas's De Excidio Britonum and the Early British Church (Woodbridge, 2009). Gerrard, James, The Ruin of Roman Britain: an Archaeological Study (Cambridge, 2013).

Halsall, Guy, Settlement and Social Organization: the Merovingian Region of Metz. (Cambridge, 1995). 
Halsall, Guy, Funny Foreigners: Laughing with the Barbarians in Late Antiquity, in: Guy Halsall (ed.), Humour, History and Politics in Late Antiquity and the Early Middle Ages, (Cambridge, 2002) 89-113.

Halsall, Guy, Gender and the End of Empire, Journal of Medieval and Early Modern Studies 34/1 (2004) 17-39.

Halsall, Guy, Barbarian Migrations and the Roman West, 376-568 (Cambridge, 2007).

Halsall, Guy, Burial Writes: Graves, »Texts«and time, in Early Merovingian Northern Gaul in: Guy Halsall, Cemeteries and Society in Merovingian Gaul: Selected Studies in History and Archaeology, 1992-2009 (Leiden, 2010) 215-231.

Halsall, Guy, The Space Between: the ,Undead Roman Empire and the Aesthetics of Salin's Style I. Paper prepared for The Sir David Wilson Lecture in Medieval Studies, UCL, October 15, 2014. Retrieved on 29 March 2017: edgyhistorian.blogspot.co.uk/2014/10/the-spacebetween-undead-roman-empire.html.

Halsall, Guy, Otherness and Identity in the Merovingian Cemetery, in: Jorge López Quiroga, Michel Kazanski, and Vujadin Ivanisevic (eds.), Entangled Identities and Otherness in Late Antique and Early Medieval Europe, BAR International Series 2852 (Oxford, 2017) 189-198.

Harland, James M, Deconstructing Anglo-Saxon Archaeology: a Critical Enquiry into the Study of Ethnicity in Fifth-Century Britain. Unpublished PhD Thesis (University of York) forthcoming.

Harland, James M , Imagining the Saxons in Late Antique Gaul, in: Matthias Hardt, Melanie Augstein, and Babette Ludowici (eds.), Sächsische Leute und Länder: The Naming and Localising of Group Identities in the First Millenium AD, Neue Studien Zur Sachsenforschung 7 (Hannover, forthcoming 2018).

Haseloff, Gunther, Die Germanische Tierornamentik der Völkerwanderungszeit. Studien zu Salins Stil I (Berlin, 1981).

Hawkes, Jane, Symbolic Lives: the Visual Evidence, in: John Hines (ed.), The Anglo-Saxons from the Migration Period to the Eighth Century: an Ethnographic Perspective (Woodbridge, 1997).

Hawkes, Sonia Chadwick and Dunning, Gerald C., Soldiers and Settlers in Britain, Fourth to Fifth Century, Medieval Archaeology 5 (1961) 1-70.

Hen, Yitzhak, The Uses of the Bible and the Perception of Kingship in Merovingian Gaul, Early Medieval Europe 7 (1998) 277-290.

Heydemann, Gerda. Biblical Israel and the Christian Gentes: Social Metaphors and the Language of Identity in Cassiodorus's Expositio Psalmorum, in: Walter Pohl and Gerda Heydemann (eds.), Strategies of Identification: Ethnicity and Religion in Early Medieval Europe (Turnhout, 2013) 143-208.

Higham, Nicholas J., The English Conquest: Gildas and Britain in the Fifth Century. (Manchester, 1994).

Higham, Nicholas J., King Arthur: Myth-Making and History (London, 2002).

Hills, Catherine, The Archaeology of Anglo-Saxon England in the Pagan Period: a Review, Anglo-Saxon England 8 (1979) 297-330.

Hustwit, Edwin R., The Britons in Late Antiquity: Power, Identity and Ethnicity. Unpublished $\mathrm{PhD}$ thesis (University of Bangor, 2014).

Hustwit, Edwin R., Britishness, Pictishness and the "Death" of the Noble Briton: the Britons in Roman Ethnographic and Literary Thought, Studia Celtica 50/1 (2017) 19-40.

Inker, Peter. The Saxon Relief Style. BAR British Series 410 (Oxford, 2006). 
Jarrett, Kirsten, Ethnic, Social and Cultural Identity in Roman to Post-Roman Southwest Britain. Unpublished PhD Thesis (University of Sheffield, 2010).

Jones, A. H. M., The Later Roman Empire, 284-602 (Oxford, 1964).

Jones, Michael E., The End of Roman Britain (London, 1996).

Jones, Siân, The Archaeology of Ethnicity: Constructing Identities in the Past and Present (London, 1997).

Lapidge, Michael, Gildas's Education and the Latin Culture of Sub-Roman Britain, in: Lapidge and Dumville, Gildas, New Approaches, 27-50.

Lapidge, Michael and Dumville, David (eds.), Gildas: New Approaches (Woodbridge, 1984).

Laycock, Stuart, Britannia: The Failed State (Stroud, 2008).

Lucy, Sam, The Anglo-Saxon Way of Death (Stroud, 2000).

Martin, Toby F., The Cruciform Brooch and Anglo-Saxon England (Woodbridge, 2015).

Marzinzik, Sonja, Early Anglo-Saxon Belt Buckles, BAR British Series 357 (Oxford, 2003).

McKinley, Jacqueline I., The Anglo-Saxon Cemetery at Spong Hill, North Elmham, Part VIII: the Cremations (Dereham, 1994).

Merrills, Andy, History and Geography in Late Antiquity (Cambridge, 2005).

O'Loughlin, Thomas, Gildas and the Scriptures: Observing the World through a Biblical Lens (Turnhout, 2012).

O'Sullivan, Thomas D., The De Excidio of Gildas: its Authenticity and Date (Leiden, 1978).

Petts, David, Christianity and Cross-Channel Connectivity in Late and Sub-Roman Britain, in: Fiona K. Haarer, Rob Collins, Keith J. Fitzpatrick-Matthews, Sam Moorhead, David Petts, and Philippa Walton (eds.), AD 410: The History and Archaeology of Late and PostRoman Britain, edited by (Oxford, 2014) 73-88.

Pohl, Walter, Romanness: a Multiple Identity and Its Changes, Early Medieval Europe 22/4 (2014) 406-418.

von Rummel, Philipp, Habitus Barbarus: Kleidung und Repräsentation spätantiker Eliten im 4. und 5. Jahrhundert (Berlin, 2007).

von Rummel, Philipp, The Fading Power of Images: Romans, Barbarians, and the Uses of a Dichotomy in Early Medieval Archaeology, in: Walter Pohl and Gerda Heydemann (eds.), Post-Roman Transitions: Christian and Barbarian Identities in the Early Medieval West (Turnhout, 2013) 365-406.

Sackett, James, Style and Ethnicity in the Kalahari: a Reply to Wiessner, American Antiquity 50/1 (1985) 154-159.

Scheschkewitz, Jonathan, Das spätrömische und angelsächsische Gräberfeld von Wasperton, Warwickshire (Bonn, 2006).

Scull, Chris, Martin Carver, Catherine Hills \& Jonathan Scheschkewitz. Wasperton: A Roman, British and Anglo-Saxon Community in Central England (Review), Antiquity 86/122 (2009) 1209-1211.

Sharpe, Richard, Martyrs and Local Saints in Late Antique Britain, in: Alan Thacker and Richard Sharpe (eds.), Local Saints and Local Churches in the Early Medieval West (Oxford, 2002) 105-120.

Sutherland, A. C., The Imagery of Gildas's de Excidio Britannie, in: Lapidge and Dumville, Gildas: New Approaches, 157-168.

Theuws, Frans, Grave Goods, Ethnicity, and the Rhetoric of Burial Rites in Late Antique Northern Gaul, in: Ton Derks and Nico Roymans (eds.), Ethnic Constructs in Late Antiquity: The Role of Power and Tradition (Amsterdam, 2009) 283-320. 
Turner, Peter, Identity in Gildas' De Excidio et Conquestu Britanniae, Cambrian Medieval Celtic Studies 58 (2009) 29-48.

Williams, Howard, A Well-Urned Rest: Cremation and Inhumation in Early Anglo-Saxon England, in: Ian Kuijt, Colin P. Quinn, and Gabriel Cooney (eds.), Transformation by Fire: The Archaeology of Cremation in Cultural Context (Tucson, 2014).

Wiseman, Howard, The Derivation of the Date of the Badon Entry in the Annales Cambriae from Bede and Gildas, Parergon 17 (2000) 1-10.

Wood, Ian N., The End of Roman Britain: Continental Evidence and Parallels, in: Lapidge and Dumville, Gildas: New Approaches, 20-21.

Wood, Ian N., Continuity or Calamity?: The Constraints of Literary Models, in: John F. Drinkwater and Hugh Elton (eds.), Fifth-Century Gaul: a Crisis of Identity? (Cambridge, 1992) 9-18.

Woolf, Alex, An Interpolation in the Text of Gildas's de Excidio Britanniae, Peritia 16 (2002) 161-167.

Wormald, Patrick, Kings and Kingship, in: Paul Fouracre (ed.), The New Cambridge Medieval History (Cambridge, 2005) 571-604. 